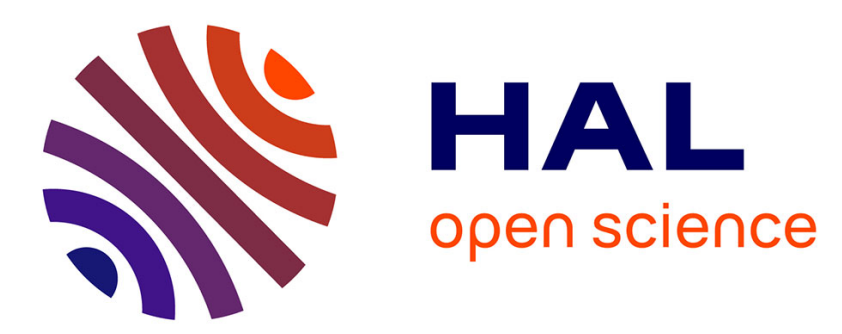

\title{
Managing interaction for learning and value creation in exchange relationships: A commentary \\ Thomas Johnsen
}

\section{To cite this version:}

Thomas Johnsen. Managing interaction for learning and value creation in exchange relationships: A commentary. Journal of Business Research, 2012, 65 (2), pp.137-138. 10.1016/j.jbusres.2011.05.012 . hal-00858328

\section{HAL Id: hal-00858328 \\ https://hal-audencia.archives-ouvertes.fr/hal-00858328}

Submitted on 5 Sep 2013

HAL is a multi-disciplinary open access archive for the deposit and dissemination of scientific research documents, whether they are published or not. The documents may come from teaching and research institutions in France or abroad, or from public or private research centers.
L'archive ouverte pluridisciplinaire $\mathbf{H A L}$, est destinée au dépôt et à la diffusion de documents scientifiques de niveau recherche, publiés ou non, émanant des établissements d'enseignement et de recherche français ou étrangers, des laboratoires publics ou privés. 


\title{
Managing Interaction for Learning and Value Creation in Exchange Relationships: A Commentary
}

Thomas Johnsen, Audencia Nantes School of Management, France

\author{
Abstract \\ This paper is a commentary to the paper by Hammervoll published in this issue, which discusses \\ the management of value creation in exchange relationships. His paper conceptualizes three \\ particular types of interaction: unilateral supplier learning, unilateral supplier development and \\ bilateral learning, and reports on a Norwegian survey to identify links between relationship \\ governance, value creation initiatives and value creation. This commentary discusses the \\ conceptualization and operationalization of these interaction types, identifying potential \\ limitations and making suggestions for further research.
}

\section{Introduction}

Despite the impressive amount of research on exchange relationships in recent years, the link to value creation and types of learning and development is potentially interesting, not least because this touches on several fields, in which I am interested, including marketing, purchasing and learning. My commentary here focuses on the three interaction types proposed and tested, the conceptual model and its operationalization, and the nature of suppliers to which the study relates. 


\section{Interaction types}

Scholars have written extensively in recent years about the interaction process between industrial customers and suppliers and the Industrial Marketing \& Purchasing (IMP) group has contributed significantly to developing this field. Hammervoll's conceptualization of interaction types builds on IMP research in addition to a range of complementary theories, including strategic management (e.g. Dyer and Singh, 1998; Borys and Jemison, 1989) and operations and supply chain management (e.g. Handfield et al, 2000). Drawing from such varied theories, Hammervoll conceptualizes three types of interaction: unilateral supplier learning, unilateral supplier development and bilateral learning.

In short, unilateral supplier learning takes place when customers supply valuable information to suppliers, such as market demand information. The paper describes sequential interaction as when one party (the customer) needs to transmit information before the other party (the supplier) can react. Unilateral supplier development concerns what one might describe as traditional supplier development where the customer coaches the supplier with a view to improving its capabilities (Handfield et al, 2000). Hammervoll asserts that the interdependence in unilateral supplier development is reciprocal, because such interdependence requires an interactive process that involves feedback loops. Finally, the paper characterizes bilateral learning as mutual learning and sharing of strategic information. Hammervoll states that bilateral learning requires reciprocity: interaction rather than action and re-action ("sequential interdependence"). 
The main problem I see with the conceptualization of the three types of interaction is the lack of clarity as to why two forms of learning exist (bilateral and unilateral) but only one form of development. Why does the model not include bilateral (supplier) development? An alternative organization of the types in a two-by-two matrix (axes being unilateral-bilateral and learningdevelopment), would reveal four types of interaction. Conceptually, bilateral supplier development therefore appears to be missing. Practically, I also think unilateral and bilateral supplier development need to be distinguished. Traditional supplier development programmes tend to assume that the development process is one-way, that is, the customer develops the supplier through activities such as on-site consultation, education and training programmes, temporary personnel transfer, and the transfer of knowledge and qualifications into the supplier's organization (Krause, 1997; Krause et al, 2000). However, some supplier development research does highlight the need for a two-way approach, for example, Forker et al's (1999) paper on "examining supplier improvement efforts from both sides". Lamming (1996) makes a similar argument for supplier development programmes to allow suppliers to pass knowledge to customers, and Modi and Mabert (2007) suggest that "collaborative communication" and "bilateral top management support" are important factors in ensuring supplier development success (although their empirical results only support the former). I am also aware of a practical example where a company implemented supplier development as bilateral development because a unilateral approach did not work: Unipart (the UK automotive supplier) initially launched a supplier development programme, asking suppliers if Unipart could develop their capabilities through a supplier development programme. However, its early implementation efforts showed a need for a two-way knowledge-sharing approach as suppliers also needed to 
develop Unipart's capabilities; Unipart decided on the name "supply development" instead of "supplier development". Such mutual development seems to be a missed opportunity so I would suggest that future typologies of interaction, focused on learning and development, incorporate the concept of bilateral supplier development.

Furthermore, why is unilateral (i.e. traditional one-way) supplier development reciprocal, when unilateral supplier learning is described as sequential? Arguably, all interaction types must have elements of interaction rather than action-reaction, but supplier development programmes usually begin with a customer initiative to improve the supplier. Therefore, an initial action by the customer usually precedes the supplier improving its capabilities. In my view, unilateral supplier development, in traditional form, is sequential, and would only become reciprocal if involving mutual (bilateral) learning.

\section{Conceptual model and operationalization}

The paper presents a conceptual model that specifies three types of value creation initiatives (information supply, coaching problem solving, and strategic knowledge sharing), and formulates hypotheses that focus on positive impacts on value creation, divided into unilateral supplier learning, unilateral supplier development, and bilateral learning). Seemingly what the model shows as three types of value creation are in fact value creation initiatives and not measures of value creation as an outcome. Handfield et al (2000) define supplier development in terms of activities (i.e. initiatives) to improve a supplier's performance and/or capability (p. 37), but Hammervoll's model seems to suggest a different causality. The paper concludes with a 
note on further research to consider other conceptualizations of (more outcome or product/service focused) forms of value creation and I think this more traditional relationship value construction would make for an interesting extension of the present study and help to avoid conceptual problems.

\section{Which suppliers?}

Finally, I am not convinced that the study captured the importance of the strategic nature of customer-supplier relationships. The main study included two control variables, focused on relationship duration and duration of experience. Whilst the long-term nature of customersupplier relationships is an important variable, this does not necessarily say anything about the extent to which a relationship is strategic. The supplier development literature, for example Forker et al (1999), suggests that supplier development be reserved for strategic supplier relationships, typically those that reflect high value and supply risk (Kraljic, 1983; Gelderman and van Weele, 2005). The study could useful have identified different types of relationships, including, for example, strategic and non-strategic.

Overall, the paper by Hammervoll makes an interesting contribution to the field and I would encourage JBR readers to read the paper.

\section{References:}


Borys Bryan, Jemison David B. Hybrid arrangements as strategic alliances: theoretical issues in organizational combinations. Academy of Management Review 1989; 14: 234-249.

Dyer Jeffrey $\mathrm{H}$, Singh Harbir. The relational view: cooperative strategy and sources of interorganisational competitive advantage. Academy of Management Review 1998; 23: 660-79.

Forker Laura B, Ruch William A, Hershauer James C. Examining supplier improvement efforts from both sides. Journal of Supply Chain Management 1999; Summer: 40-50.

Gelderman, Cees J. and van Weele Arjan J. Purchasing portfolio models: a critique and update. Journal of Supply Chain Management 2005; 41 (3) Summer: 19-28.

Handfield Robert B, Krause Daniel R, Scannell Thomas V, Monczka Robert M. Avoid the pitfalls in supplier development. Sloan Management Review 2000; Winter: 37-49.

Kraljic Peter. Purchasing must become supply management. Harvard Business Review 1983; Sept.-Oct.: 109-117.

Krause Daniel R. Supplier development: current practices and outcomes. International Journal of Purchasing and Materials Management 1997; 33 (1): 12-9.

Krause Daniel R, Handfield Robert B, Scannell Thomas V. An empirical investigation of supplier development: reactive and strategic processes. Journal of Operations Management 1998; 17: 39-58.

Lamming, Richard C. Squaring lean supply with supply chain management. International Journal of Operations and Production Management 1996; 16 (2): 183-196.

Modi, Sachin B. and Mabert Vincent A. Supplier development: improving supplier performance through knowledge transfer. Journal of Operations Management 2007; 25 (1): 42-64. 